\title{
Imaginación y resistencia antidictatorial en los años ochenta. La acción por América Latina de la Asociación Internacional de Defensa de Artistas Víctimas de la Represión en el Mundo (AIDA)
}

\author{
Imagination and anti-dictatorial resistance in the 80's. The action for Latin \\ America of the International Association for the defense of artists victims of \\ the repression worldwide (AIDA)
}

\author{
Moira Cristiá*
}

\begin{abstract}
Resumen: Fundada en 1979, AIDA tenía como objetivo denunciar a través de acciones creativas la censura y la violencia sufridas por artistas en cualquier parte del mundo. Iniciada en Francia, esta asociación se extendió rápidamente por Holanda, Alemania, Bélgica, Suiza y Estados Unidos. El presente artículo intenta analizar la manera en la que AIDA actuó en la esfera pública transnacional para ejercer presión respecto a las violaciones de los Derechos Humanos de las dictaduras latinoamericanas, estudiando en particular su "campaña por los cien artistas argentinos desaparecidos". Potenciada por la presencia de exiliados argentinos en el comité ejecutivo de la asociación de París, dicha campaña consistió en una serie de manifestaciones de solidaridad en distintas ciudades que incluyó marchas, conciertos, elaboración de pinturas y postales, así como un libro sobre la represión cultural publicado en París y, poco después, en Madrid. A partir de documentos escritos, visuales y audiovisuales, prensa y entrevistas, este artículo procura reponer esas experiencias de manera de reflexionar sobre la creación como forma de resistencia y de acción contra el autoritarismo en el mundo.
\end{abstract}

Palabras clave: solidaridad internacional, historia transnacional, artistas, Derechos Humanos, dictaduras latinoamericanas

\begin{abstract}
Founded in 1979, AIDA aimed to denounce, through creative actions, censorship and violence suffered by artists all over the world. Created in France, this association reached Holland, Germany, Belgium, Switzerland and the United States of America. This paper aims to analyze how this association acted in the transnational public sphere to put pressure on Latin American regimes in relation with Human Rights violations. This work will specially study AIDA's "campaign for the 100 argentine artists disappeared". Boosted by the presence of some Argentine exiles in the executive committee in Paris, this campaign included different solidarity demonstrations in different cities, concerts, paintings and postcards, as well as a book on cultural repression published in Paris and, shortly after, in Madrid. Based on written, visual and audiovisual documents, press and interviews, this article seeks to
\end{abstract}


reconstruct these experiences in order to reflect on creation as a form of resistance and action against authoritarianism in the world.

Keywords: international solidarity, transnational history, artists, Human Rights, Latin American dictatorships

Recibido: $16 / 06 / 2017$

Aceptado: 30/07/2017

\section{Introducción}

En julio de 1979, la directora de teatro Ariane Mnouchkine y el cineasta Claude Lelouch brindaron una conferencia de prensa en París sobre la crítica situación de la cultura en el Cono Sur. Tras una gira motivada por su preocupación por los actores de Teatro Aleph de Chile ${ }^{1}$, los franceses denunciaron la censura, represión de artistas y listas negras en aquella región, afirmando contundentemente que "se mata gente desde adentro" al imposibilitar la creación ${ }^{2}$. Meses después, en diciembre de ese año, dichos intelectuales publicarían en el diario Le Monde el manifiesto fundacional de una asociación, bajo el título "La Libertad es como una piel de zapa"3. Allí denunciaban los abusos en distintos países y expresaban su voluntad de defender la libertad de creación artística en todo el mundo. Los firmantes aclaraban que "los artistas perseguidos son sólo la parte visible de un siniestro y gigantesco iceberg" 4 . Conformada en octubre, AIDA (Association internationale de défense des artistes victimes de la répression dans le monde) tomó personalidad jurídica el 3 de diciembre de 1979, cuando fue inscripta como asociación civil en la Prefectura de Policía de París ${ }^{5}$. Poco después, se alquiló un local en un subsuelo de un edificio ${ }^{6}$ para que

\footnotetext{
* Argentina. Doctora en Historia y Civilizaciones por l'École des Hautes Études en Sciences Sociales (París). Becaria Posdoctoral del Consejo Nacional de Investigaciones Científicas y Técnicas de Argentina (CONICET), en el Instituto de Investigaciones Gino Germani. Mail: moicristia@gmail.com.

${ }^{1}$ Sobre este caso en particular, los miembros participantes y el funcionamiento internacional de AIDA, consultar: Moira Cristiá, "Solidaridad e identidad artística transnacional. Reflexiones sobre la experiencia de l'Association internationale de défense des artistes victimes de la répression dans le monde (1979/1983)”, Nadia De Cristóforis y Susana Novick (Comp.) Jornadas. Un siglo de migraciones en la Argentina contemporánea, Instituto de Investigaciones Gino Germani, Universidad de Buenos Aires, Buenos Aires, 2016, 2-19. Disponible en:

http://pobmigraiigg.sociales.uba.ar/publicaciones/libros/.

${ }^{2}$ Henri Serniès, "Campagne pour la défense des artistes victimes des dictatures", Le Matin de Paris, 17 de julio de 1979 ; Lucien Curzi, "Mnouchkine et Lelouch témoignent. Au Chili on tue les gens de l'intérieur", L'Humanité, 17 de julio de 1979.

3 "La Peau de chagrín" fue el título de una novela de Honoré de Balzac de 1831 que trata de un joven que recibe una piel de zapa o cuero mágico que le permitía satisfacer sus deseos pero que se encogía con cada uno de ellos. Desde entonces la expresión se utiliza para designar aquello que se reduce inevitablemente por el uso. Así, en dicho texto, los fundadores de la asociación afirman los límites de la libertad en distintos países, puesto que ejercerla haría que se la limitara cada vez más. Ariane Mnouchkine y Claude Lelouch, "La liberté est comme une peau de chagrin", Le Monde, 21 de diciembre de 1979.

${ }^{4}$ Idem.

${ }^{5}$ Récépissé de la Préfecture de Paris, 03/12/1979. [Archivo particular de Jean-François Labouverie].

${ }^{6} 6$, rue de l'Eure (sous-sol), 75014 Paris.
} 
la asociación adquiriera mayor autonomía respecto a la compañía de Mnouchkine, el Théâtre $d u$ Soleil, cuyas instalaciones la albergaron en sus inicios ${ }^{7}$.

El objetivo de AIDA sería repudiar la censura y represión de la cultura a través de manifestaciones en las que el arte fuera la herramienta para la denuncia, combatiendo la violencia con imaginación y más creación. El logo de la asociación -circular, con una franja cruzada y de color rojo-, evoca los típicos sellos de censura, pero en este caso invirtiendo su sentido. En vez de silenciar, la intención de AIDA era usar los medios propios a los artistas para sacar a la luz aquello que la represión intentaba esconder. En la presentación de la asociación, en un volante de 1981, se subrayaba de la siguiente manera el repudio a que artistas de diferentes latitudes sufrieran la represión:

(...) por expresar sus ideas, porque relatan hechos reales. Los artistas, ya sean escritores, cineastas, músicos o pintores, fotógrafos o escultores, son intimidados, censurados, prohibidos, encerrados, encarcelados, torturados, asesinados en países donde la razón de Estado prohíbe toda crítica, toda libertad de expresión o de opinión, donde ella sirve de argumento en ausencia de pruebas $^{8}$.

Por ello, AIDA se proponía “romper el silencio que rodea la represión, defendiendo la libertad de expresión, creación y trabajo de los artistas, en cualquier lugar del mundo en el que ésta se encontrara amenazada" ". Desde su concepción, sus fundadores consideraron la necesidad de que fuera internacional, por lo que rápidamente se extendió, además de a diferentes ciudades de Francia, a otros cinco países: Alemania, Suiza, Holanda, Bélgica y Estados Unidos. Con características particulares en cada uno de ellos, los comités ejecutivos de los distintos países tomaban las principales decisiones y coordinaban sus acciones en reuniones internacionales regulares. En tanto su accionar consistía en la adopción de casos, es importante resaltar que, al menos desde 1983, una de las condiciones para evitar que se malinterpretaran sus fines era que los artistas defendidos no hubiesen tomado las $\operatorname{armas}^{10}$. Sin embargo, al menos en el caso de los artistas argentinos, los miembros exiliados callaban datos que pudieran obligar a sacar de la lista de las víctimas a algunos de ellos. Además de poder comprender las razones que los habrían llevado por ese

\footnotetext{
${ }^{7}$ El compromiso de Ariane Mnouchkine en relación a las injusticias en el mundo no comienza ni culmina con la experiencia de AIDA. Para más información sobre su teatro y su acción política, consultar: Béatrice Picon-Vallin, Ariane Mnouchkine, Paris, Actes Sud Editions, 2016.

${ }^{8}$ Volante "Cent bannières dans Paris pour cent artistes disparus en Argentine", 1981. Salvo aclaración, los documentos citados pertenecen a los archivos AIDA, reunidos en La Cartoucherie, París. Precisamos que todas las traducciones de este artículo son de la autora.

${ }^{9}$ Volante "Cent bannières...", op. cit.

${ }^{10}$ Este tema se discutió en la reunión internacional de 1983, cuando un representante de AIDA Holanda (Aad Hoetjes) afirmó que era difícil determinar cuando un artista era reprimido por su actividad artística o por su militancia política. Ariane Mnouchkine respondió que era necesario aclarar los límites y no defender a un militante armado aunque su causa fuese justa. Tras la discusión se acordó aclararlo en el estatuto de la asociación, pero desconocemos si ese cambio fue finalmente realizado. Actas de la reunión internacional, París, 18 de junio de 1983.
} 
camino, implícitamente acordaban que nada justificaba el abuso de poder por parte del Estado $^{11}$.

En este artículo se intentará demostrar que AIDA, funcionando como una suerte de red de solidaridad gremial, combinó el trabajo conjunto de exiliados y de locales para ejercer presión desde distintas latitudes sobre los gobiernos nacionales que censuraban la creación considerada subversiva y violaban Derechos Humanos. Con ese fin, se analizará en primer lugar las características generales de las primeras acciones organizadas por América Latina. En segundo lugar, se estudiarán los dos tipos de acciones llevadas a cabo en distintos países (contrainformativas y de manifestación pública) en el marco de la campaña por los "cien artistas argentinos desaparecidos". Concentrando principalmente la atención en la manifestación organizada por la sede fundacional de París, se apuntará a demostrar la manera en la que AIDA actuaba en la esfera pública transnacional ${ }^{12}$. Cruzando fuentes periodísticas, documentos y testimonios orales ${ }^{13}$ se buscará reconstruir la importante actividad solidaria desarrollada en distintos puntos de los países centrales dinamizada por esta asociación respecto al caso argentino ${ }^{14}$.

\section{I - Despertar la solidaridad internacional: primeras acciones por América Latina}

En un folleto impulsado por la sección Holanda en 1982, se señalaba que AIDA "adopta casos específicos por los cuales estima poder obtener resultados reales, mediante una acción bien dirigida". Con sus esfuerzos, la asociación se proponía colaborar, en la medida de lo posible, con otras organizaciones similares, como Amnesty international, sin limitarse al envío de telegramas o a la presentación de peticiones. AIDA apuntaba a organizar acciones "espectaculares" destinadas a llamar la atención del público sobre casos específicos de artistas víctimas de la represión de diferentes países y, en ciertas ocasiones, a

\footnotetext{
${ }^{11}$ Recordemos que el mismo Envar El Kadri había participado de la resistencia peronista en los sesenta y del intento fallido de guerrilla rural en Taco Ralo en 1968 (Tucumán), encontrándose entre los fundadores de las Fuerzas Armadas Peronistas. Por su compromiso sufrió prisión, tortura, amenazas de muerte y finalmente exilio. Sobre esta figura, puede consultarse: Eduardo Anguita y Martín Caparrós, La voluntad. Una historia de la militancia revolucionaria en la Argentina, Tomo 1 (1966 - 1973), Buenos Aires, Planeta/Booket, 2006; Alejandro Tarruella, Envar "Cacho” El Kadri. El guerrillero que dejó las armas, Buenos Aires, Sudamericana, 2015.

${ }^{12}$ Cuando utilizamos esta definición hacemos referencia a una ampliación del concepto de esfera pública de Jürgen Habermas, con la que el teórico alemán denomina el ámbito comunicativo donde se gesta la opinión pública, y donde ésta puede expresarse como fuerza política ciudadana tanto en contraposición a los poderes privados como presionando al Estado. En nuestro mundo globalizado, las pujas de poder entre diferentes actores (nacionales y transnacionales) con los Estados-nación se encuentran sujetos a un control ciudadano transnacional. Sobre esta transformación del fenómeno político, ver: Nancy Fraser, et al, Transnacionalizing the Public Sphere, Cambridge, Polity Press, 2014.

${ }_{13}$ Agradezco a Ana Longoni por sugerirme el estudio de esta asociación, y especialmente a Liliana Andreone, por abrirme los archivos de AIDA y los suyos personales, así como en brindarme contactos de quienes fueron miembros de la asociación. Este trabajo también debe reconocimiento al aporte de Jean-François Labouverie y de todos aquellos que brindaron documentos, recuerdos o comentarios.

${ }^{14}$ Debemos aclarar que no se pretendía limitar la acción a dichos países. Por el contrario, se proyectaba crear AIDAs en otros países como Colombia, Perú y Polonia. Cf. Cuaderno de Actas de AIDA.
} 
enviar delegaciones de artistas a esos territorios para relevar información de primera mano $^{15}$.

Como fue mencionado, el surgimiento de AIDA se enmarca en la visita de Mnouchkine y Lelouch a Chile repudiando las violaciones a los Derechos Humanos de las dictaduras del Cono Sur, sin ser ésta causa exclusiva de su acción. De hecho, entre los primeros casos adoptados se encuentra también el del escritor checo Vaclav Havel, cuyo juicio fue reconstruido en una obra de teatro dirigida por Ariane Mnouchkine en París y luego reproducida en distintas ciudades ${ }^{16}$. Sin embargo, es innegable que el interés de la asociación por América Latina se alimentó de la importante recepción de exiliados de esos países, así como de una sensibilidad particular de las izquierdas europeas por los movimientos revolucionarios en dicho continente. En particular el caso chileno, cuya política era más fácilmente comprensible y asimilable para los europeos que la de otros países, movilizó una importante solidaridad ${ }^{17}$.

En contraste, la situación argentina, y en particular el fenómeno del peronismo, generaba una gran incomprensión, ya que no existía equivalente en el panorama político europeo. No obstante, las dimensiones que cobraron las violaciones de los Derechos Humanos en dicho país le otorgaron protagonismo en la agenda de distintas organizaciones humanitarias. Esta preocupación impulsó el Coloquio internacional "La política de desapariciones forzadas de personas" que se llevó a cabo en la Asamblea Francesa en París entre el 31 de enero y el $1^{\circ}$ de febrero de $1981^{18}$. Si la presencia latinoamericana en Europa fue fundamental para poner sobre el tapete la situación en la región, para el caso de AIDA no es un dato menor que tres de los 32 miembros del comité ejecutivo de la sede "fundacional" fueran exiliados argentinos, lo cual funcionó como un motor para denunciar las violaciones de Derechos Humanos en dicho país en particular, así como en los países vecinos, facilitando además los vínculos con personas y asociaciones latinoamericanas.

No es entonces sorprendente que, además del inicial apoyo a los actores del Teatro Aleph, se encontraran entre los primeros casos adoptados por AIDA el de Alba González Souza: una pianista uruguaya y militante del Frente Amplio que, tras el golpe de Estado en su país en 1973, se exilió en Argentina, país en donde su hijo fue secuestrado y

\footnotetext{
${ }^{15}$ Dossier "L'Argentine: 100 artistes disparus / Argentina: 100 artists disappeared", AIDA international, marzo de 1982, p. 1.

16 "Le procès de Prague", estrenada en la Cartoucherie en febrero de 1980, fue reconstruida a partir de los testimonios que Patrice Chéreau reunió en su viaje a Praga. A pesar de habérsele denegado el acceso al recinto del juicio, el intelectual se abocó a escribir los relatos que los familiares que habían sido autorizados a asistir le transmitieron al salir del mismo. Además, Chéreau dirigió y filmó la puesta en escena de Mnouchkine, actuada por Simone Signoret e Yves Montand, en Múnich. Ésta fue difundida por la televisión local y comprada por un canal austríaco, cuyas señales alcanzaban buena parte del territorio checo. (Cf. "Procès de Prague. Les saltimbanques brisent le huis clos", Le Point, 18 de febrero de 1980). Además, la obra de teatro se presentó en distintas ciudades europeas y en Estados Unidos, alcanzando un número importante de espectadores. (Cf. Actas de las reuniones de AIDA, 1980).

${ }^{17}$ Caroline Moine, "'Votre combat est le nôtre'. Les mouvements de solidarité internationale avec le Chili dans l'Europe de la Guerre froide", Monde(s), 2 : 8, Rennes, 2015, 83-104.

${ }^{18}$ Consultar informe: "El caso argentino: desapariciones forzadas como instrumento básico y generalizado de una política. La doctrina del paralelismo global. Su concepción y aplicación. Necesidad de su denuncia y condena. Conclusiones y recomendaciones", Paris, 1981.
} 
desaparecido en $1976^{19}$. La pianista fue finalmente detenida junto a dos compañeros en un nuevo exilio en Colombia, el 3 de enero de 1979, por circular con documentos falsos, temiéndose su extradición al Uruguay ${ }^{20}$. Mientras que otras organizaciones, como Amnesty International, recurrieron principalmente al envío de cartas exigiendo su liberación -lo cual habría impresionado a los militares ${ }^{21}$ - AIDA combinó las cartas individuales y de personalidades, las peticiones y los conciertos de solidaridad (en Hamburgo, Múnich, La Haya $^{22}$ ) con una creativa manifestación: un concierto ambulante.

El 19 de abril de 1980, un piano fue trasladado sobre una plataforma con ruedas por las calles de París, desde Opéra hasta la Embajada de Colombia, mientras que diecisiete pianistas se turnaban para ejecutar el repertorio ${ }^{23}$. Esta actividad fue publicitada bajo el título "Concierto para piano libre y artista prisionera" y fue repetida en Aviñón unos meses más tarde ${ }^{24}$. Además, se firmaron peticiones y se llevaron a cabo acciones ante dicha embajada en París, La Haya y Bonn. Tras su liberación en septiembre de 1980 y su refugio en Francia ${ }^{25}$, Alba participó activamente en las manifestaciones de solidaridad realizadas por AIDA y otras organizaciones específicamente dedicadas a América Latina ${ }^{26}$.

Otro de los primeros casos latinoamericanos adoptados por AIDA fue el de Liber Forti, director de teatro anarquista argentino preso en Bolivia en julio de 1980. En su caso, se organizó una campaña de telegramas que colaboró a su liberación y recepción en París en octubre de ese año ${ }^{27}$. También se solicitó la liberación de Juan Baladan Gadea, guitarrista y compositor uruguayo prisionero en el Penitenciario "Libertad" desde 1971, donde había compartido reclusión con el pianista Miguel Ángel Estrella ${ }^{28}$. Para ello, AIDA Holanda propuso la creación de dos postales en su nombre que eran enviadas de manera individual al penitenciario para ejercer presión. Este caso generó conflicto dentro de la asociación, cuando en la reunión internacional de junio del 1983 se discutió el espinoso

\footnotetext{
${ }^{19}$ Se trata de Rafael Laudelino Lezama González, secuestrado en Buenos Aires el 1 de octubre de 1976. Se presume que se trató de un operativo conjunto uruguayo-argentino. Su legajo puede consultarse en: http://sdh.gub.uy/inicio/documentos/fichas_de_desaparecidos/argentina/lezama_gonzalez_rafael_laudelino. Sobre la colaboración de las fuerzas de represión en la región, leer: Melisa Slatman, "El Cono Sur de las dictaduras, los eslabonamientos nacionales en el interior de la Operación Cóndor y las particularidades del caso argentino", Gabriela Águila, Santiago Garaño y Pablo Scatizza (eds.), Represión estatal y violencia paraestatal en la historia reciente argentina. Nuevos abordajes a 40 años del golpe de Estado, La Plata, EDULP, 2016, 451-471.

${ }^{20} \mathrm{Se}$ los acusaba de ser militantes de Tupamaros llegados a Colombia para entrenar militarmente a miembros del M-19. Eduardo Mackenzie, Les Farc ou l'échec d'un communisme de combat-Colombie 1924-2005, Paris, Publibook, 2005, p. 389.

21 “Alba, enfin libre!”, Panorama Aujourd'hui, no 143, noviembre de 1980.

22 "Concet in Vrijheid voor gevangen pianiste", Haasche Courant, 18 de abril de 1980.

${ }^{23}$ Folleto de información AIDA, s/d, circa 1984. Entre ellos Claude Helffer, Noël Lee, Catherine Collard, Jean-Claude Pennetier, Bruno Rigutto, Dominique Merlet, Jean-Philippe Collard y Frédérique Fontanarosa. Cf. Claude Samuel, "Concerto pour un piano libre", Le Point, 14 de abril de 1980.

${ }^{24}$ Volante de información "L'AIDA a un an", s/d, circa noviembre 1980.

25 “Libération. Les victoires d'A.I.D.A.”, Le Quotidien de Paris, 30 de septiembre de 1980.

${ }^{26}$ Por ejemplo, la gala en homenaje a uno de los fundadores de Tupamaros Raúl Sendic, organizada por Droits socialistes de l'homme realizada en el Grand Palais, el 11 de diciembre de 1980. En esta ocasión, Alba tocó el piano por primera vez desde su liberación junto al cantante Daniel Viglietti. Invitación dedicada para los miembros de AIDA.

${ }^{27}$ Volante "Action urgente pour Liber Forti”, AIDA, aprox. 1980.

${ }^{28}$ El pianista argentino Miguel Ángel Estrella, preso en Uruguay entre 1977 y 1980, era acusado de colaborar con la organización Montoneros. La campaña internacional por su liberación fue encabezada principalmente por Yves Haguenauer, bajo la presidencia nominal de Nadia Boulanger y Yehudi Menuhin.
} 
tema de la lucha armada. En tanto se sospechaba que el artista pertenecía a Tupamaros, se decidió abandonar el caso, colocando al comité de Holanda, que ya había impulsado actividades por él, en una posición delicada ${ }^{29}$.

Además de estos casos mencionados, uno de los antecedentes a la importantísima campaña por Argentina en la que se embarcó AIDA, fue el boicot a la Semana de Cine francés que se desarrolló en Buenos Aires del 20 al 28 de marzo de $1980^{30}$. Dicha actividad, co-organizada por la asociación de promoción de cine francés en el mundo (Unifrance), con el auspicio del diario argentino Clarín y la compañía aérea Air France, consistió en la elección y difusión de dieciocho películas galas, entre las cuales figuraba una protagonizada por Yves Montand ${ }^{31}$. Mientras que un grupo de actores fueron convocados, la ausencia de su nombre en la lista de invitados a Argentina se debía, seguramente, a su manifiesto compromiso político. Su participación en los reclamos que se realizaban los días jueves al mediodía frente a la Embajada de dicho país -simultáneamente a la ronda las Madres de Plaza de Mayo en Buenos Aires- fue probablemente determinante. En este contexto, el proyecto comercial generaba una controversia similar a la del Mundial de Fútbol de 1978²: ¿Había que rechazar la invitación para repudiar lo que sucedía en Argentina? ¿O acaso debían aceptarla e intentar actuar desde Buenos Aires?

Tras una discusión interna, AIDA decidió repudiar la participación, denunciando este gesto como "colaborador" con un régimen que violaba los Derechos Humanos y que no respondía ante los reclamos que se le presentaban. Por ello, la asociación publicó su posición en distintos diarios franceses, empujando a los organizadores y participantes a justificar su postura ${ }^{33}$. Por ejemplo, se publicó en el diario Le Monde un manifiesto contundente firmado por artistas de renombre ${ }^{34}$ sosteniendo que si los participantes de la Semana de Cine francés pensaban que podían separar arte y política se equivocaban, pues estaban siendo cómplices de un régimen "que viola derechos, asesina y hace desaparecer".

En ese documento, los firmantes solicitaban a los invitados que no asistieran, o al menos no en esas condiciones, y si lo hacían, que memorizaran los nombres de cuatro artistas desaparecidos: del cineasta Raymundo Gleyzer, del actor Jesús Fernández, del actor y director de teatro Gregorio Nachmann, y de la actriz Sylvia Kuperman de Arnaudo. Con cierta ironía, los invitaban a retener dichos nombres para preguntar a las autoridades por ellos, pues "no [podían] esperar que [recordaran] los otros 15.000"35. Ante esta acusación

\footnotetext{
${ }^{29}$ En la misma situación se encontraba otro caso que había sido sugerido por Mario Benedetti, el del dramaturgo Mauricio Rosencof, preso desde 1971. En tanto estaba acusado de pertenecer a Tupamaros, ni AIDA ni el Pen Club Internacional lo adoptaron.

${ }^{30}$ Una situación similar fue la de la visita de la Orquesta de París a Buenos Aires. AIDA intentó ejercer presión publicando un manifiesto en Le Monde en julio de ese año. Ver: Esteban Buch, Música, dictadura, resistencia. La orquesta de París en Buenos Aires, 1980, Buenos Aires, FCE, 2016, 19-20.

31 En la carta del presidente de la asociación Yves Rousset-Rouard publicada en su boletín se transmite el interés comercial que representa el mercado latinoamericano. Es por ello que alientan el viaje de sus miembros a Buenos Aires e incluso la visita de uno o dos países más de la región. Cf. Boletín interno Unifrance Film, № 2, febrero de 1980.

${ }^{32}$ Sobre este tema y el asociacionismo de exiliados argentinos en Francia, consultar los trabajos de Marina Franco, en particular su libro El exilio. Argentinos en Francia durante la dictadura, Buenos Aires, Siglo XXI, 2008.

${ }^{33}$ Por ejemplo, "Boycotter l'Argentine", Le Matin, 12 de marzo de 1980.

${ }^{34}$ René Allio, Loleh Bellon, Henri Cartier-Bresson, Patrice Chereau, Costa-Gavras, Laurent Heynemann, Claude Lelouch, Ariane Mnouchkine, Yves Montand, Michel Piccoli, Simone Signoret y Fernando Solanas.

35 “Quatre artistes", Le Monde, 12 de marzo de 1980.
} 
pública de complicidad, los actores que aceptaron viajar a Argentina publicaron una respuesta y sostuvieron con firmeza: "Que quede claro: no vamos para darle la mano al General Videla ni para glorificar un régimen que reprobamos con todas nuestras fuerzas". Por el contrario, afirmaban que creían que visitando el país podrían servir más eficazmente "a las ideas y las libertades"36.

Estas declaraciones resultaban hipócritas a los oídos de los miembros de AIDA, ya que la supuesta independencia del festival de cine respecto a instituciones oficiales o gubernamentales argentinas que alegaban sus organizadores ${ }^{37}$ se comprobaba falsa en los diarios locales. Por ejemplo, según el diario La Prensa del 8 de marzo ${ }^{38}$, este evento era auspiciado por la Secretaría de Cultura de la Ciudad de Buenos Aires y del Instituto Nacional de Cine y Artes Audiovisuales (INCAA) ${ }^{39}$. Para ejercer mayor presión, un grupo de representantes de asociaciones de familiares de víctimas asistieron al aeropuerto Charles de Gaulle de París el día de la partida de los invitados franceses para solicitarles que intervinieran frente a las autoridades y exigieran información sobre los desaparecidos. Al regresar de su estadía en el país sudamericano, los actores participantes declararon en el diario Le Monde, que varios de ellos se habían reunido en Buenos Aires con integrantes del Sindicato de Industria Cinematográfica Argentina y de la Asociación Argentina de Actores, con los que habrían organizado una conferencia de prensa. El testimonio publicado parece buscar minimizar la situación de represión en Argentina:

Como artistas, no podemos no gritar cuando los hombres que desean expresarse por la música, el teatro, no pueden. En un país donde la censura existe, podemos temer que lo que digamos sobre la libertad de expresión, sobre las libertades humanas, los valores esenciales de los Derechos Humanos, no se acepten. Sin embargo, no fue el caso. Lo que hicimos fue escuchado, reproducido por la prensa con algunas excepciones $^{40}$.

Además, la actriz Danièle Delorme solicitó una reunión con el Presidente francés Giscard d'Estaing para informarle sobre los resultados de su visita. Por su parte, el productor de cine y presidente de Unifrance Yves Rousset-Rouard manifestó su satisfacción y afirmó el éxito del evento que se evidenciaba en la cobertura brindada por la prensa argentina y en la afluencia de espectadores ${ }^{41}$. Evidentemente el interés empresarial y la publicidad de la que productores y actores asistentes se beneficiaban, los llevó a obviar la colaboración con el régimen que el acontecimiento podía significar. Al fin y al cabo, el evento contribuía a consolidar la imagen de normalidad y paz que la cúpula buscaba transmitir por distintos medios. Si bien la denuncia pública de AIDA no alcanzó para frenar

\footnotetext{
36 "Faut-il boycotter l'Argentine", Le Matin, 14 de marzo de 1980.

37 "Précisions sur une visite à Buenos Aires", Le Monde, 15 de marzo de 1980.

${ }^{38}$ Notas de AIDA sobre la controversia del Festival de Unifrance, archivos AIDA, 1980.

${ }^{39}$ Además, en la descripción de la inauguración, se remarca la presencia del secretario de información pública de la Presidencia de la Nación, el General Antonio Llamas y el Secretario de la Cultura de la Municipalidad Ricardo Freixa, entre otras autoridades oficiales. Clarín, 16 de marzo de 1980.

${ }^{40}$ Catherine Humblot, “Danièle Delorme et l'Argentine”, Le Monde, 27 de marzo de 1980.

${ }^{41}$ Jean-Pierre Lenôtre "Retour d'Argentine", Le Nouveau Film Français, 28 de marzo de 1980, p. 1 y 2.
} 
la organización del evento, generó suficiente ruido para obligar a los participantes a tomar ciertas precauciones para intentar conservar un discurso limpio de responsabilidad ante la opinión pública francesa.

Otro de los antecedentes que deben mencionarse es el proyecto de realización de un film que AIDA titularía Les artistes qui se battent pour les droits de l'homme ("Los artistas que luchan por los Derechos Humanos"). La idea surgió para aprovechar el paso de Adolfo Pérez Esquivel por París antes de recibir el Premio Nobel de la Paz el 10 diciembre de 1980 en Noruega y la visibilidad internacional que el mismo otorgaba a la situación política latinoamericana. Aunque desde 1974 se dedicara enteramente a la defensa de los Derechos Humanos, el honrado argentino era escultor y había trabajado como profesor de Bellas Artes, dato que interesaba particularmente a $\mathrm{AIDA}^{42}$. Si en un principio se pensó realizar una simple entrevista filmada y montarlo con otros testimonios, finalmente se decidió organizar un almuerzo con un grupo de artistas que habían atravesado experiencias similares de manera de registrar una charla informal sobre estos temas. Se invitó al pianista argentino Miguel Ángel Estrella, al actor y director del teatro Aleph Óscar Castro, a la pianista uruguaya Alba González Souza y al director de teatro argentino Liber Forti, quienes habían estado presos en Uruguay, Chile, Colombia y Bolivia respectivamente y habían recibido entonces el apoyo de AIDA. A este grupo se sumaba Augusto Boal, actor y director de teatro que había sufrido la prisión de la dictadura brasileña y luego el exilio.

El proyecto establecía que se filmaría a cinco artistas latinoamericanos que se habían comprometido con sus pueblos y habían sido castigados por ello, por lo que se consideraba que todos "habla[ba]n la misma lengua". La idea era reunirlos y provocar una situación informal (por ejemplo, alrededor de un mate o compartiendo un vino), considerando que de esa conversación surgirían elementos interesantes tanto para el público europeo como para el latinoamericano. La intención era que olvidaran las cámaras para que emergieran naturalmente comentarios, chistes, anécdotas, dando lugar a una conversación auténtica y sincera. En el documento que se le hizo llegar a los participantes se establecía el siguiente objetivo:

Nosotros no queremos hacer algo "militante", sino algo profundamente HUMANO. (...) Nosotros vamos a filmar una reunión de amigos... Uds. lo son aún cuando no se conozcan personalmente, porque vuestra amistad nace de estar de acuerdo con las cosas fundamentales de la vida, de saber que han pasado pruebas muy duras y siguen enteros, de que "a pesar de todo" siguen tirando pa lante..." (...) Y a nosotros nos toca hablar por los que no pueden... Nos toca aprovechar el cachito de notoriedad que nos han dado, que no hemos buscado, para ayudar a nuestros hermanos ${ }^{43}$.

En el proyecto, se planteaba que la película no sólo serviría para informar sobre la realidad latinoamericana, sino que también demostraría que numerosos artistas no se

\footnotetext{
42 Adolfo Pérez Esquivel fundó la asociación "Paz y Justicia” para defender la causa en América Latina. Por su militancia por los Derechos Humanos sufrió secuestro, tortura y prisión por 14 meses, entre agosto de 1977 y octubre de 1978. ${ }_{43}$ Apuntes sobre el proyecto de película "Los artistas que luchan por los derechos humanos", 1980. Las mayúsculas y resaltados pertenecen al original.
} 
conformaban con desempeñar su rol profesional y asumían un compromiso social. Uno de los ejes de debate que se pretendía desplegar durante la película se ejemplificaba en el hecho que Adolfo Pérez Esquivel hubiera prácticamente abandonado la actividad artística: ¿Cómo debían participar los artistas en su sociedad? ¿Cómo comprometerse con la misma? El film podría entonces transmitirse por televisión y proyectarse en mesas redondas u otro tipo de actividades para difundir la tarea que asumió AIDA ${ }^{44}$.

Sin embargo, si bien el almuerzo se concretó y fue filmado, la película, que duraría unos 20-25 minutos una vez montada, no se finalizó. La clave de que este proyecto quedara trunco, según los testimonios recogidos, fue que el resultado no fue el deseado. Las transcripciones de las cintas grabadas permiten aprehender la disconformidad que las derivas de la conversación despiertan en Ariane Mnouchkine. No mucho después de comenzar, la directora de la asociación interpeló a los invitados y les solicitó olvidar la cámara, amenazando con desechar esos casetes si no encontraba más autenticidad en sus palabras $^{45}$. Así, este proyecto fílmico inconcluso demuestra un cúmulo de tensiones internas y desacuerdos que la misma militancia artística generaba.

Los casos puntuales adoptados por AIDA aquí mencionados, además del boicot del Festival de Cine Francés y el proyecto de película, permiten visualizar el accionar de la asociación desde la denuncia y el debate sobre casos de censura o violencia estatal en distintas regiones del mundo, tanto por medios más tradicionales -como la toma de posición en la prensa- como por otros más creativos, como la elaboración de postales, la realización de una película y la organización de conciertos. Estos mismos elementos también se reproducirán, con ciertas diferencias, en la amplia campaña por Argentina que analizaremos a continuación.

\section{II - La campaña por los “cien artistas argentinos desaparecidos": contra- información y presión internacional}

Más allá de los casos particulares adoptados por AIDA y los otros antecedentes mencionados, es interesante profundizar en una campaña más vasta titulada "Cien artistas argentinos desaparecidos", la cual generó una importante repercusión en los distintos núcleos de la asociación. Iniciada en 1981, esta campaña contó con dos grandes tipos de acción, aunque en muchos casos aparezcan combinados: la contra-información que buscaba difundir datos puntuales de lo que sucedía en Argentina y la manifestación "espectacular",

\footnotetext{
${ }^{44}$ Se filmó en video color el miércoles 3 de diciembre de 1980 de 12:00 a 15:45 en la casa particular de Sonia Debeauvais, directora de relaciones públicas del Théâtre Nationale Populaire de Jean Vilar. El camarógrafo fue Juan Incháustegui, fotógrafo vasco refugiado en Francia que habitualmente cumplía funciones de vigilancia en el Thèàtre du Soleil. Aunque se desconoce el paradero de las cintas de filmación, el principal contenido de las mismas fue transcripto en dos manuscritos mecanografiados (uno para los diálogos en español y otro en francés).

${ }^{45}$ Sostiene que lo se enuncia está filtrado por un discurso de tono oficial ("langue de bois”). Transcripción de la cinta en francés. La conversación entre los invitados transcurre mayoritariamente en castellano, salvo las intervenciones de Ariane Mnouchkine, del escritor Claude Roy y del jurista Louis Joinet. Además de la anfitriona, del camarógrafo y de los franceses mencionados, también estaban presentes Jean-François Labouverie, Envar El Kadri, Liliana Andreone y Odile Cointepas, ayudando en el despliegue del almuerzo durante el cual se rodó la conversación. Entrevista telefónica con Liliana Andreone, 2 de agosto de 2016; intercambio electrónico con Jean-François Labouverie, 20 de septiembre de 2016.
} 
que apuntaba a la expresión colectiva y a la sensibilización de la opinión pública europea a través de actos con una fuerte dimensión simbólica. Respecto a la primera vía de acción debe resaltarse que, en un folleto de difusión, AIDA explica su consternación ante la larga lista de actores, directores, pintores, músicos, escritores, cineastas, estudiantes de Bellas Artes, cantantes, escultores y fotógrafos desaparecidos recibida de la Comisión de Familiares de Desaparecidos y Presos por razones políticas de Buenos Aires. Ante la dificultad de elegir un solo caso, como solían funcionar, se decidió tomar su conjunto como un caso colectivo, expresándolo de la siguiente forma:

"Pensamos que la situación en Argentina, desafortunadamente, es tan excepcional que se debía también tomar medidas excepcionales. Entonces AIDA asume estos 100 artistas como un solo caso y convoca a apoyar su procedimiento para recuperarlos con vida" 46

Si bien ese número de artistas eran nombrados, individualizando sus obras y trayectorias, se aclaraba que sólo se trataba de una muestra de la violencia que se estaba ejerciendo en ese país. La cifra redonda aportaba una fuerza significativa a la campaña y podía representar más que un número concreto, transmitiendo la idea de la magnitud de la represión ejercida ${ }^{47}$.

Una de las primeras manifestaciones de la campaña se hizo en Alemania, más precisamente en el cine "Arii" de Múnich, donde se organizó una velada por Argentina el 23 de junio de 1981. Schrei wo du kannst, Argentina ("Grita donde puedas, Argentina") combinó la lectura de textos de argentinos traducidos al alemán, cartas y testimonios, con música (una obra del austríaco Alban Berg, otra de Astor Piazzola) tocada por Alba González Souza. Entre los textos también se leyó un fragmento de la novela de Reinhard Lettau Frühstücksgespräche in Miami ("Conversaciones de desayuno en Miami”, 1977) en la que el escritor alemán y estadounidense expulsado de su país natal por criticar el servilismo de la prensa, imaginó las charlas plagadas de sadismo que tendrían un grupo de dictadores sudamericanos refugiados en aquella ciudad balnearia. Para este evento se requirió un trabajo colectivo importante, entre actores que leyeron los textos, un escenógrafo, el dramaturgo y director de teatro Wolfgang Kunz quien concibió la idea general, así como la colaboración de numerosas personas para traducir, organizar y promocionar la actividad. Asimismo, en ese marco se editó un cuadernillo de 16 páginas con algunos de los escritos, de manera de difundir ampliamente la situación de Argentina ${ }^{48}$.

Otra de las iniciativas realizadas por esta causa fue la elaboración en Francia de un libro colectivo llamado Argentine: Une culture interdite (Pièces à conviction 1976/1980) que fue publicado por la editorial Maspero ${ }^{49}$ de París y luego en español por la editorial

\footnotetext{
${ }^{46}$ Volante "L'Argentine: 100 artistes disparus", AIDA, 1981.

${ }^{47}$ Bajo ese título contundente se desplegaba la lista, en la que en realidad había 109 nombres. La lista de los artistas participantes tampoco coincidía con el número exacto del título de la campaña.

${ }^{48}$ Cuadernillo "Schrei wo du kannst, Argentina", AIDA Bundesrepublik Deutschland e. V., 1981.

${ }^{49}$ Se trata de la editorial de François Maspero, una las grandes difusoras de textos contestatarios en los años sesenta y setenta. Este intelectual poseía una librería reconocida llamada "La joie de lire", donde concurrían intelectuales de distintas latitudes. Además fue él quien se encargó de la edición francesa de la revista cubana Tricontinental, lo que le valió la censura, multas y prisión. En 1982, su editorial pasó a ser dirigida por François Gèze, adoptando el nombre de $L a$
} 
Revolución de Madrid. El proyecto fue propuesto a François Maspero en abril de 1981, presentándolo como el intento de demostrar con documentos diversos el plan sistemático de represión de una cultura popular e intelectual determinada, a la que el régimen juzgaba como peligrosa. El libro describe esta situación de una manera particular: reuniendo recortes de artículos de diarios argentinos para mostrar la información que se registraba allí a pesar de la censura de los medios de comunicación por el aparato de control de la dictadura. Los artículos, organizados por área de la vida cultural, se completaban con relatos de artistas e intelectuales que testimoniaron desde el exilio sobre la represión en los distintos campos artísticos de la cultura argentina (televisión, radio, prensa escrita, artes plásticas, cine, música, teatro, etc.). Los compiladores se proponían así combinar esa "antología de la prosa militar" con las palabras de víctimas y testigos directos ${ }^{50}$.

Un prólogo emotivo de Miguel Ángel Estrella y un epílogo reflexivo de Julio Cortázar enmarcaron los relatos de personalidades como Mercedes Sosa, Eduardo Galeano y Fernando Solanas que se referían a sus respectivas áreas profesionales, poemas de Juan Gelman y Vicente Zito Lema, e ilustraciones de Ricardo Carpani e Ignacio Colombres que graficaban la censura. El cuidadoso trabajo de recopilación realizado mayoritariamente por Envar El Kadri y Liliana Andreone, bajo el pseudónimo de "Juan José Hernández Arregui”, fue posible gracias a que sus familiares y amigos les enviaban periódicos desde Argentina. También por la gentileza del Comité contre la Faim et le Développement que les autorizó recibir correspondencia a nombre de uno de sus miembros, de manera de no despertar sospechas de los servicios de inteligencia argentinos. Además de las contribuciones de artistas e intelectuales exiliados, algunos colaboradores franceses trabajaron arduamente para que este libro fuera posible, traduciendo y corrigiendo el manuscrito. Entre ellos, se contó con el aporte de Sophie Moscoso ${ }^{51}$, del actor del Soleil Georges Bonnaud, y del intelectual François Gèze, quien había vivido en Argentina entre 1974 y $1976^{52}$.

El libro de AIDA reunía noticias que funcionaban como rastros de la represión de aquellos que pensaban, escribían, pintaban y creaban en Argentina por fuera de la línea dispuesta por los militares. Desde la prohibición de "El principito" de Saint-Exupéry ${ }^{53}$

Découverte desde el año siguiente. Sobre dicho editor, en relación a otros dos editores de materiales contestatarios en Italia y Alemania, consultar: Julien Hage, Feltrinelli, Maspero, Wagenbach : une nouvelle génération d'éditeurs politiques d'extrême gauche en Europe occidentale, 1955-1982. Histoire comparée, histoire croisée, Tesis de Doctorado dirigida por M. Jean-Yves Mollier, Université de Versailles - Saint-Quentin-en-Yvelines, 2010.

${ }^{50}$ Presentación proyecto titulado “Argentine: mort d'une culture?", abril de 1981.

${ }^{51}$ Se trataba de la esposa de Roberto Moscoso, el escenógrafo del Soleil de 1789, una de las primeras obras de gran repercusión de la compañía. Sophie Moscoso era entonces asistente de dirección de Ariane Mnouchkine.

52 Como opción al Servicio militar, el sistema francés permitía cumplir el servicio al Estado en la cooperación internacional. Durante su estadía en Buenos Aires, Gèze entrevistó a El Kadri en varias ocasiones para su investigación sobre la situación revolucionaria argentina. Dicho trabajo lo condujo a escribir, junto al sociólogo Alain Labrousse, un libro titulado Argentine: Révolution et contre-révolutions (éditions du Seuil, 1975). Asimismo, una vez llegados Envar y Liliana a París, fue Gèze quien los invitó a las reuniones que se realizaban en el 14 de la rue Nanteuil, en los albores de lo que sería el COBA (Collectif pour le Boycott de l'Organisation de la Coupe du Monde en Argentine). Finalmente, también fue éste el principal vínculo con la editorial Maspero, donde se publicaría el libro Argentine: une culture interdite (Entrevista telefónica con Liliana Andreone, 2 de agosto de 2016).

${ }^{53}$ Este dato representa un verdadero guiño para el público francés, para quien la censura de una obra literaria de amplia difusión en el público infantil revela concretamente la dimensión de la represión ideológica en el país sudamericano. Ver por ejemplo, el comentario que se hace sobre el libro en el artículo "Cent peintures contre la dictature argentine", publicado en Le Matin de Paris, el 14 de noviembre de 1981. 
hasta los arrestos de espectadores en recitales de rock, pasando por la interpelación de Mercedes Sosa, al asesinato o desaparición de periodistas, y la prohibición de tangos, todos estos indicios contribuían a denunciar un plan sistemático de silenciamiento de una visión de la realidad. La tapa de la edición francesa fue dibujada por Héctor Cattolica, el ilustrador argentino radicado en París desde los años sesenta, quien personificó botas con gorros de militares, caricaturizando un régimen que implantaba un orden hegemónico por la fuerza. Para la edición española fue Ignacio Colombres el responsable de una portada más expresionista, en la que la fuerza de los colores vivos y el desborde de las formas transmiten la violencia de esa coyuntura.

Poco después, un cuadernillo de 35 páginas en francés e inglés fue elaborado en Holanda para brindar información sobre los casos de artistas desaparecidos argentinos, de manera de que pudiera circular por los medios de prensa o ser distribuidos a particulares. $\mathrm{Su}$ portada presenta una imagen de gran impacto: un grupo de cabezas sin rostro tachadas con una cruz roja, indicando gráficamente la eliminación física de individuos. En su interior, tras la presentación, se publicó una carta abierta de la asociación al General Galtieri sosteniendo que en Europa la imagen de Argentina se transformó profundamente al saberse del sufrimiento al que eran expuestos sus artistas e intelectuales. Por lo tanto, a través de la misma se exigía información sobre los desaparecidos y, finalmente, se afirmaba que en todos los países existía una Plaza de Mayo, donde los artistas esperaban la liberación de los suyos ${ }^{54}$.

Conjuntamente con ese material, se elaboraron volantes sobre algunos de los casos más reconocidos de esta lista, como el de Haroldo Conti o el de Héctor Oesterheld. Con referencias sobre sus carreras, estos documentos indicaban claramente que se trataba de sólo un caso de los 100 artistas que AIDA reclamaba y exigía que aparecieran con vida. Extendiendo el reclamo aún más, en el volante sobre Conti se citaba un fragmento de una entrevista a Julio Cortázar de 1978 en el que este último afirmaba que mientras que una figura como la del escritor desaparecía, la misma suerte corrían "numerosas personas del pueblo, militantes, obreros y campesinos"55. Y que cuando él los nombraba (e indirectamente AIDA asumía la misma postura), se evocaban también a todas esas otras víctimas.

Otro de los casos particulares dentro de esta campaña que mereció una actividad importante, fue el de Remo Berardo. Por este artista plástico se organizó una exposición itinerante $^{56}$, durante la cual se ofrecía a la venta un catálogo de su obra por 10 Francos, así como el libro Argentine: une culture interdite al valor de 30 Francos. También se ponía a disposición material gratuito sobre AIDA, así como folletos y postales de Amnesty International a favor de la familia Berardo ${ }^{57}$. El catálogo no sólo cumplía su función

\footnotetext{
${ }^{54}$ Carta abierta al General Leopoldo Fortunato Galtieri, presidente de la República Argentina, firmada por las seis AIDAs y fechada en marzo 1982. En la firma aparece la palabra "Cueco", tal vez refiriéndose a que la redacción de la carta es de autoría del artista y escritor francés Henri Cueco. Cf. Cuadernillo "L'Argentine: 100 artistes disparus...”, op. cit., p. 2.

${ }^{55}$ Entrevista de Miguel Rojas Mix con Julio Cortázar, Échanges, junio de 1978, citado en folleto AIDA “Où est Conti?".

${ }^{56}$ Dicha exposición, de unos cuarenta cuadros, se encontraba en Suecia en junio de 1983 pero se proponía a los diferentes comités de AIDA para que circulara por otros espacios. Actas de la reunión internacional del AIDA redactadas por Envar El Kadri, París, 18 de junio de 1983.

57 "Notes pour les organisateurs de l'exposition de tableaux de Remo Berardo", s /d.
} 
tradicional, sino que también aparecía como una prueba de la represión de la dictadura argentina en lo referido a la cultura, extendiéndolo al resto de la sociedad. Esta pieza gráfica, concebida solidariamente por la agencia MAGMA, denunciaba visualmente la violencia en el hecho de que todas sus páginas estaban dividas en dos como si hubieran sido rasgadas, dato acentuado por el contraste entre el blanco de la mitad superior y el negro de la parte inferior.

Conjuntamente con las reproducciones de obras, se reunía allí una serie de textos que describían la desaparición de Remo, tras haber denunciado la de su hermano Amado. Mientras éste último era sospechado por realizar tareas de alfabetización en la villa 31 de Buenos Aires, el primero participaba de la organización de familiares de desaparecidos reclamando información sobre el paradero de su hermano. Remo Berardo fue parte de las víctimas de la infiltración de Alfredo Astíz en ese movimiento incipiente que se organizaba en torno a la Iglesia de la Santa Cruz, junto con Azucena Villaflor y las monjas francesas Alice Domont y Léonie Duquet, desaparecidos en la misma semana de diciembre de 1977. El catálogo señalaba que además del secuestro del pintor se habían extraído de su taller obras de otros artistas reconocidos como Benito Quinquela Martín, dato que demostraba la rapiña que el mecanismo de secuestro permitía. Si el caso de Amado y Remo se enmarcaba en la violencia en el campo cultural, al avanzar en las páginas del catálogo también se extiende al resto de las víctimas argentinas, que Amnesty International calculaba, hasta entonces, en unas 15.000 personas.

Hacia el final del catálogo, el testimonio de la madre de dos militantes desaparecidos, Catalina de Guarini, resaltaba la represión del movimiento de los familiares de desaparecidos, y destacaba el trabajo de AIDA como fundamental para sensibilizar la opinión pública mundial, incomodando fuertemente al gobierno argentino. Según ella, no había como los artistas para denunciar más notoriamente los crímenes, utilizando los medios artísticos para generar impacto. En la contratapa del catálogo se publicó un último texto firmado por la Comisión de Familias de Desaparecidos y Presos por razones políticas en Argentina, generalizando el caso de los hermanos Berardo a la situación que vivían muchas familias argentinas e interpelando al lector con la pregunta: “¿Conoces algo más fuerte que mi esperanza?"58. Así, el catálogo cumplía una función informativa respecto de la violación de los Derechos Humanos en Argentina, además de promocionar la acción de AIDA y, por supuesto, reproducir obras del artista argentino que la exposición reunía.

\section{III - Sensibilizar a través del arte: manifestaciones “espectaculares” en Europa}

Además de la contra-información mencionada, la campaña de los artistas argentinos desaparecidos apuntaba a combinar el savoir-faire de distintos artistas para comprometer emocionalmente la opinión pública transnacional. En las discusiones entre los miembros de AIDA se alegaba que el uso recurrente de la recolección de firmas había "devaluado" su impacto, por lo que debían pensar un proyecto de gran alcance con una minuciosa atención

${ }^{58}$ Catálogo "Remo Berardo. Peintre ‘disparu` à Buenos Aires le 8.12.1977”, s/d. 
estética que fuera superadora de esa práctica ${ }^{59}$. Para el mismo se impulsó la campaña "100 pintores para 100 artistas 'desaparecidos' en Argentina”, solicitando la elaboración de esa cantidad de pinturas que representaran el número de la lista de artistas desaparecidos confeccionada para la ocasión ${ }^{60}$. Organizado por área de expresión, el listado de nombres, apellidos y fecha de desaparición de artistas fueron elegidos como ejemplo de la represión cultural que sufría la Argentina ${ }^{61}$.

Aunque se dio plena libertad a los pintores participantes respecto al motivo visual y la técnica, se solicitó que se expresaran sobre un lienzo de dos por tres metros, dispuesto de manera horizontal o vertical, según lo prefirieran. AIDA ponía a disposición telas, enduído, pigmentos, barniz de protección y un espacio para elaborarlas (uno de los talleres de $L a$ Cartoucherie) de lunes a viernes de 9 a $18 \mathrm{~h}$, solventando así los gastos de producción ${ }^{62}$. Asimismo, algunos artistas usaron sus propios materiales, respetando los lineamientos señalados. Este criterio apuntaba a darle una unidad a la diversidad estética de banderas que los artistas de distintos orígenes, corrientes y trayectorias diferentes elaboraron para esta causa $^{63}$. Pinturas figurativas, otras abstractas, surrealistas, expresionistas, paisajes, símbolos, palabras, todo un amplio espectro de expresiones estaban presentes en el conjunto de obras.

Las pinturas, perforadas a lo largo de su extremo superior, se disponían gracias a un sofisticado sistema de transporte y exposición de los lienzos que el escenógrafo del Soleil Guy-Claude François ${ }^{64}$ diseñó inspirándose en los dispositivos utilizados para una manifestación en Japón. Su construcción era simple pero delicada pues requería 3 personas para desplazar las pinturas, además de cierto conocimiento de cómo manipularlas. Se trataba de dos cañas de bambú (material elegido por ser a la vez fuerte y liviano) atadas en forma de cruz, de la cual colgaba el lienzo. Por las perforaciones realizadas en la línea superior de la tela, se enhebraba una cuerda que la sostenía a la caña horizontal. Además,

\footnotetext{
${ }^{59}$ Entrevista con Liliana Andreone, Buenos Aires, 25 de junio de 2016.

${ }^{60}$ Una versión preliminar del estudio de esta campaña fue presentada bajo el título "Crear en el espacio público transnacional contra la violencia de Estado. Estudio del caso de la campaña "Cien artistas argentinos desaparecidos" (1981/1982) de la Asociación Internacional de Defensa de Artistas Víctimas de la Represión en el Mundo (AIDA)" en III Jornadas "Exilios políticos del Cono Sur en el siglo XX. Agendas, problemas y perspectivas conceptuales", Museo de la Memoria y los Derechos Humanos, Santiago de Chile, 9, 10 y 11 de noviembre de 2016.

${ }^{61}$ Carta convocando la colaboración de pintores bajo el título "100 pintores para 100 artistas 'desaparecidos' en Argentina desde el Golpe de Estado de 1976", AIDA, octubre 1981.

${ }^{62}$ Idem.

${ }^{63}$ Cuando se describe la marcha en Ámsterdam en el dossier publicado en marzo de 1982, se destaca la presencia de obras de artistas de la talla del búlgaro Christo y el húngaro naturalizado francés Victor Vasarely (Dossier "L'Argentine: 100 artistes disparus...", op. cit., p. 9). Sin embargo, estos dos nombres no aparecen en la lista de artistas que elaboraron las 100 pinturas-banderas, publicada en un folleto sobre la campaña de París. Allí se registran sólo 91 apellidos de artistas. (Cf. Lista publicada en "Cent bannières dans Paris pour cent artistes disparus en Argentine", 1981). Probablemente, algunos de ellos hayan realizado más de una, como puede sospecharse de una serie de tres banderas muy visibles en la marcha de Holanda. Mientras que la primera reproducía un elemento central de una obra canónica del arte occidental - el Adán que pintó Michelangelo en la Capilla Sixtina del Vaticano -, la segunda sólo dejaba ver la mitad derecha de la pintura puesto que la otra mitad de la bandera había sido cubierta de negro con la palabra manuscrita "Argentina" apareciendo en blanco. Finalmente, la tercera de la serie se encontraba íntegramente en negro, ahora con la inscripción completa en blanco. Este tríptico móvil sugería al espectador el avance de la acción de la censura y de la violencia frente a la cultura en Argentina.

64 (1941/2014) Diseñó la escenografía del Soleil desde L'âge d'or en 1975 hasta Le Dernier Caravansérail en 2003.
} 
otra soga atada en cada uno de los dos extremos inferiores permitía que una persona de cada lado sostuviera la bandera extendida. Por la cantidad y calidad del material que se utilizaría, se realizó un entrenamiento sobre el montaje del material y su transporte, seguido de un ensayo en el parque de La Cartoucherie. Siguiendo los procedimientos del teatro, cada paso había sido reflexionado con antelación para que la manifestación "espectacular" se diera sin inconvenientes, generando el efecto estético y el impacto emocional buscados.

La primera marcha pública de esta campaña se llevó a cabo el 12 de septiembre de 1981 en la ciudad de Ámsterdam. Como punto de encuentro se eligió la iglesia Moses Aaron Kerk de la Waterloo Plein, una calle de doble mano del centro de la capital holandesa donde circula un tranvía, a 200 metros de la casa-museo de Rembrandt (Rembrandthuis) y de la ópera-ballet nacional (National Opera and ballet). En ese evento inaugural, moderado en cuanto al número de concurrentes pero simbólicamente poderoso, se probó el manejo de las pinturas-banderas, con unos quince ejemplares ya terminados que habían comenzado a realizarse desde junio ${ }^{65}$. Además, cien personas marcharon en fila india vestidas de negro, con una suerte de bolsa de arpillera en la cabeza ${ }^{66}$ (perforada a la altura de los ojos) y con un cartel que indicaba uno de los nombres de las víctimas. Así, cada manifestante de la fila prestaba su cuerpo para representar a uno de aquellos de los que se desconocía su paradero. Otro elemento simbólico fue que el desfile se realizó detrás de un camión en el que se trasladaba una campana que sonaba llamando a la solidaridad ${ }^{67}$. También se escuchaban algunas melodías compuestas para esta ocasión, tocadas por los músicos presentes. Más allá de esta marcha, la campaña en Holanda también contó con la elaboración de una docena de postales con imágenes de diferentes artistas ${ }^{68}$. Además, un dibujo del reconocido artista francés Roland Topor fue elegido como imagen icónica de esta causa, reproducida en postales y afiches que se pegaron en distintos puntos de la ciudad.

La mayor manifestación de la campaña fue la de París del 14 de noviembre de 1981, comenzando a las 11 de la mañana de aquel sábado. Tres días antes de la marcha, AIDA publicó un anuncio en el diario Libération con algunas fotografías de las pinturas, informando del evento y solicitando la colaboración de 400 personas para llevar las banderas, distribuir los volantes y pegar los afiches. Para que el acontecimiento tuviera un mayor impacto visual, se invitaba a los manifestantes a vestirse de negro y a llevar un pañuelo blanco "como hacen las madres de la Plaza de Mayo todos los jueves en Buenos

\footnotetext{
${ }^{65}$ Descripción de la campaña redactada por Envar El Kadri (firmada con el pseudónimo Cachò) y publicada en Testimonio Latinoamericano. Dicha revista, editada en Barcelona por Álvaro Abós y Hugo Chumbita, reproducía textos enviados por exiliados de distintas nacionalidades -aunque en su mayoría argentinos-, radicados en distintos países europeos y latinoamericanos. "Cien banderas por cien artistas", Testimonio Latinoamericano, № 11, diciembre 1981, p. 33.

${ }^{66}$ El objeto elegido para cubrir los rostros quizás buscaba hacer referencia a los métodos de tortura.

${ }^{67}$ Fotografía aérea de Gerda Van Veen, publicada en el cuadernillo "L'Argentine: 100 artistes disparus", AIDA international, 1982, p. 9. También fue utilizada para la difusión de la asociación en la contratapa de la revista Testimonio Latinoamericano relatando el despliegue de la marcha. Cf. Testimonio Latinoamericano, $\mathrm{N}^{\circ}$ 9/10, octubre 1981, contratapa.

${ }^{68}$ Postales de la campaña por los artistas argentinos desaparecidos.
} 
Aires"69. Así, un símbolo que había servido de bandera de este movimiento de repudio en Argentina, era adoptado en otras latitudes para acompañar su lucha ${ }^{70}$. Este acontecimiento artístico, bajo la dirección de Ariane Mnouchkine, apuntaba a renovar la forma de acción contra la represión y por la libertad de creación y expresión. Por eso, se articuló el trabajo creativo de distintas personas, además de los colaboradores y asistentes.

Además del trabajo de los cien pintores que elaboraron las banderas y de los colaboradores voluntarios, unos cien músicos tocaron la melodía compuesta para esta ocasión por Gilbert Artman (compositor fundador de la banda llamada Urban Sax) que identificaría la marcha. El trabajo conjunto de tantas personas se definía por criterios coreográficos y escenográficos que fueron esenciales para establecer el recorrido de la marcha. También participaron los actores del Théâtre du Soleil, varios fotógrafos (entre ellos Martine Frank, miembro fundador y fotógrafa oficial de dicha compañía, y su esposo, el célebre Henri Cartier-Bresson) así como cineastas -Fernando Solanas ${ }^{71}$ y Anne Barbey $^{72}$ - que registraron la experiencia, realizando nuevos productos artísticos a partir de estos materiales. Se calcula que un total de entre 5.000 y 7.000 personas participaron del evento $^{73}$, entre las cuales algunas personalidades argentinas como Julio Cortázar y Miguel Ángel Estrella, junto a otras francesas y extranjeras como los actores Yves Montand y Simone Signoret, los cineastas Costa Gavras y Patrice Chéreau, los cantantes Jean Ferrat y Marcel Amont, los escritores Marek Halter y Hélène Cixous. Además, el Ministro de Cultura Jack Lang y la Primera Dama Danielle Mitterrand, si bien no asistieron, hicieron llegar cartas de apoyo ${ }^{74}$.

\footnotetext{
${ }^{69}$ Libération, 11 de noviembre de 1981. Fotografías de David Boeno, Torregano Collectif Presse. Se trata de imágenes captadas en el galpón que el Soleil concedió para la elaboración y guardado de las pinturas, así como durante el ensayo realizado en el parque la Cartoucherie.

${ }^{70}$ Sobre el surgimiento de este símbolo como modo de identificación, cohesión y manera de hacerse visibles en el espacio público, ver: Ulises Gorini, La rebelión de las Madres, tomo 1, Buenos Aires, Norma, 2006, 117-119. Sobre diferentes aspectos de la dimensión visual del movimiento de Derechos Humanos que fue gestando en Argentina, consultar: Ana Longoni, "Fotos y siluetas: dos estrategias en la representación de los desaparecidos", Emilio Crenzel (eds.), Los desaparecidos en la Argentina. Memorias, representaciones e ideas (1983-2008), Buenos Aires, Biblos, 2010, 35-57.

${ }^{71}$ Solanas integró parte de estas imágenes en su película "El exilio de Gardel” (1985, Argentina/Francia, 118'), junto con otras que rodó posteriormente para reconstruir el evento con los actores del film e integrarlo a su ficción. Allí se identifican amigos y familiares como figurantes, como es el caso de su hija, Victoria Solanas, así como el hijo adolescente del artista plástico Luis Felipe Noé, el actualmente reconocido cineasta Gaspar Noé. También se filmaron imágenes del taller de la Cartoucherie que se prestaba a los artistas para realizar sus pinturas, donde aparece Envar El Kadri levantando una de las banderas.

${ }^{72}$ Esta dramaturga y directora de teatro, elaboró un documental de 11 minutos sobre la experiencia que se titula precisamente “¿Dónde están?”, disponible en la Biblioteca Nacional de Francia, en París. Este documento tenía aparentemente sólo una función de registro y no habría sido difundido por ningún circuito. Entrevista telefónica a Anne Barbey, 6 de junio de 2016.

${ }^{73}$ La primera cifra es la que difundió la agencia de prensa estadounidense Associeted Press, según aparece en el artículo publicado en el diario La Nación en Argentina ("París: Marcha por los desaparecidos", La Nación, domingo 15 de noviembre de 1981, p. 4). Mientras que el dossier editado por AIDA Holanda en 1982 reproduce ese mismo número (Dossier "L'Argentine: 100 artistes disparus...", op. cit. p. 10), "Cacho" El Kadri estima la presencia de 7.000 manifestantes (cf. "Cien banderas por cien artistas", art. cit.).

${ }^{74}$ La carta de Jack Lang, en la que además se compromete a recibir artistas que se encontraran en situación de solicitar asilo en Francia, fue reproducida en la última página del dossier de información realizado en Holanda. Dossier "L'Argentine: 100 artistes disparus...", op. cit. p. 32.
} 
Si cada detalle había sido pensado en un sentido estético, el itinerario se estudió de la manera con la que se define el rodaje de una película, buscando las locaciones ideales para establecer el relato ${ }^{75}$. La presencia de los músicos no es un dato menor ni escapa a la minuciosa concepción de la manifestación. Urban Sax no es una banda convencional, sino que su funcionamiento se basa en una experimentación con el principio de la espacialización sonora y arquitectural, construyendo diferentes escenas que rodean al público y que permiten el desplazamiento del sonido alrededor de los auditores ${ }^{76}$. Como lo indica su nombre, la banda suele romper la frontera infranqueable entre espectadores/espectados para irrumpir en el espacio público de la ciudad, circular entre los asistentes y presentar espectáculos concebidos como performances. Surgido en 1973 con sólo ocho músicos, Urban Sax integró un número importante de saxos de toda la gama de esta familia (sopranos, altos, tenores y barítonos bajos) de manera de poder experimentar con su diversidad, el espacio y el movimiento. En tanto los saxos ofrecen movilidad, Artman explora el desplazamiento del sonido junto a la recepción de un público que se encuentra también en movimiento.

Otro de los principios que adopta Artman en la composición de la melodía es el desarrollo de espirales polirítmicos, buscando interrogar al público en una performance visual y sonora. Se trata de una música semi-repetitiva, con piezas evolutivas de diferentes colores y tonos. Esta característica, y el hecho de realizarse en manifestaciones colectivas, en muchos casos en celebraciones públicas, recuerdan el rol de la música en los rituales tradicionales, incentivando la emoción y la implicancia del individuo ${ }^{77}$. La dimensión visual que desarrolla la banda con un vestuario particular y con un movimiento coreografiado de los músicos, en ciertas ocasiones se combina con la presencia de bailarines. En la mayoría de las oportunidades, aunque no es el caso de la marcha de París, los saxofonistas del grupo usan overoles blancos, atuendo que los uniformiza y despersonaliza, asociándolos en un cuerpo colectivo. En definitiva, Artman estudia cuidadosamente el uso del espacio urbano como soporte de la puesta en escena, preparando la espacialización de sus intervenciones, detalladamente construidas, coreografiadas y escenografiadas $^{78}$.

\footnotetext{
${ }^{75}$ De esta tarea se encargaron algunos actores del Soleil, como Antoine Del Pin y Jean-Baptiste Aubertin, que recorrieron la zona para definir el itinerario. La selección de las locaciones dio lugar a un plano que debió ser presentado y aprobado en la Prefectura de París para obtener la autorización necesaria para llevar a cabo la manifestación. (Cf. Entrevista telefónica con Antoine Del Pin, 9 de junio de 2016). Se trata de un recorrido excepcional para una marcha, las cuales suelen desarrollarse en vías más periféricas, por ejemplo, entre Denfert-Rochereau, Place de la Nation y Place de la République.

76 Para más información e imágenes, consultar el sitio oficial de la banda que se encuentra aún en actividad: http://urbansax.com/

77 Las melodías rituales se caracterizan precisamente por un sonido continuo que favorece el transe. Esa búsqueda de emular la función ritual asignada a la música en sociedades tradicionales explica que Urban Sax haya realizado conciertos con amerindios de Vancouver, con bailarines javaneses en Yakarta o músicos sufíes en Turquía. Cf. "Gilbert Artman \& Urban Sax", Archie Patterson, Music \& Second Culture Post Millennium, Portland, Eurock, 2013, 32-39.

${ }^{78}$ Por ejemplo, en febrero de ese año - meses antes de su participación en la marcha de París - Urban Sax había intervenido el Carnaval de Venecia, por lo que incluyeron máscaras blancas en su vestuario. Cf. Marie-Ange Poyet y Bénédicte Delesalle, Urban Sax à Venise (1981,10'33'), disponible en URL: https://www.youtube.com/watch?v=WxH3F6WGLjk
} 
En este caso, la dimensión visual de la marcha coordinaba el movimiento de los músicos y el desfile de pinturas-banderas. Esa búsqueda estética y simbólica se refleja en el recorrido definido por los organizadores: comenzando en el Panteón (monumento nacional ubicado en la lo alto de la colina Saint-Geneviève donde descansan restos de grandes hombres de Francia), los manifestantes descendieron la rue Soufflot (calle que traza una diagonal desde dicho monumento hasta la rue Saint Michel y los jardines de Luxemburgo), pasaron frente al teatro Odéon, luego atravesaron el Pont Neuf, cruzando por la punta oeste de la isla de la Cité, bordearon el Museo Louvre por la rue Rivoli, recorrieron los jardines de Tullerías a lo largo hasta llegar a la última fuente previa a la Concorde. Así, la marcha atravesó el corazón de la ciudad, circulando frente a monumentos y espacios urbanos de gran poder simbólico, núcleo de la cultura francesa y referente de la cultura occidental.

Por la dificultad del traslado del material, por el peso que tenían las banderas -que difería según los tipos de telas y cantidad de capas de pintura que contenían- y por el efecto que generaba el incremento de la masa de manifestantes, se establecieron etapas: mientras que un grupo realizaría el recorrido completo, otros se irían sumando a lo largo del itinerario. El desfile estuvo encabezado por algunos músicos (saxos y tambores), un grupo de madres de Plaza de Mayo $^{79}$ con su clásico pañuelo blanco sobre sus cabezas, acompañadas por las veinte pinturas-banderas más livianas. Entre ellas se encontraba en primer plano aquella en la que tres siluetas negras $\sin$ rostro $^{80}$ aparecían junto a la pregunta: “¿Dónde están? / Où sont-ils ?”.

En la segunda posta, frente al Teatro de Odeón, se sumaban veinte pinturas más, mientras que en el Boulevard Saint-Germain-des-Près y la rue de l'Ancienne Comedie, esperaban también un grupo de músicos. Al llegar al Pont Neuf, que contrariamente a lo que indica su nombre es el puente más antiguo de París, otras veinte banderas y un grupo musical latinoamericano se agregó al desfile. Las mismas habían sido previamente distribuidas en los balcones-mirador del puente, para exponerlas más estéticamente al público y a las cámaras. Con el mismo objetivo, en el tramo de la rue de Rivoli, las banderas fueron colocadas de tres en tres, ocupando todo el ancho de la calle. Finalmente, en la intersección de la rue de Rivoli con la rue du Louvre se sumaron las últimas cuarenta banderas, que completaron el conjunto de las $\operatorname{cien}^{81}$.

Una vez alcanzado el destino final, todas las pinturas-banderas desfilaron frente a la vista del público para ubicarse en dos niveles detrás del escenario preparado para la ocasión. De esa manera, se hacía uso de la "geografía" de los jardines para coreografiar la marcha: las banderas bordeaban la fuente, lo que las obligaba a un recorrido circular, y se aprovechaban las rampas y los balcones de los dos extremos de la plaza para ubicar las pinturas en exposición. Sobre el escenario se encontraba Alba González Souza tocando el bandoneón junto a la foto de identidad de su hijo desaparecido, y el letrero "Où est mon

\footnotetext{
${ }^{79}$ Según el artículo del diario La Nación, dos madres habría viajado desde Argentina para participar de este evento. Cf. "París: Marcha por los desaparecidos", art. cit. Considerando las imágenes televisivas, pareciera tratarse de Carmen Lapacó y María Adela Antokoletz.

${ }^{80}$ Tal vez fue esta tela una inspiración que habría impulsado a El Kadri a sugerir la idea de las siluetas en Argentina, según los testimonios reunidos por Longoni y Bruzzone, que le atribuyen a él ese impulso. Ver: Gustavo Bruzzone y Ana Longoni (eds.), El siluetazo, Buenos Aires, Adriana Hidalgo Editora, 2008, p. 14.

${ }^{81}$ Relato de Envar El Kadri en "Cien banderas por cien artistas", art. Cit.
} 
fils? Rafael Lezama, uruguayen. Détenu et disparu le $1^{\text {er }}$ octobre 1976 en Argentine"82. A los tangos de Alba, le siguieron los saxofonistas repitiendo la melodía de la marcha y, finalmente, el acto terminó con la lectura de cada uno de los cien nombres de los artistas desaparecidos seguida de la pregunta del público: “¿Dónde están?”83. La manifestaciónespectáculo culminó hacia las tres de la tarde, después de cuatro horas en las que se expresó la solidaridad de una manera artística ${ }^{84}$. Esta creación colectiva fue, en definitiva, una puesta en escena fuertemente simbólica en la que las imágenes, la música y el silencio de la contemplación estética reemplazaron los discursos tradicionales.

$\mathrm{Si}$ las tres cadenas francesas de televisión difundieron imágenes de esta marcha ${ }^{85}$, extendiendo la recepción del evento más allá de los participantes directos, la campaña por los artistas argentinos desaparecidos también repercutió en otras ciudades como Dijon y Ginebra, además de conciertos en esa última ciudad, en Múnich y en Colonia. Un eco transatlántico de la campaña se produjo en Washington, donde se organizó una suerte de reunión-manifestación en febrero de 1982. En vez de desplegarse en un espacio público, la misma se realizó en el hogar de una pareja de miembros del AIDA local (Cynthia y David Birnbaum, artista y abogado respectivamente), en cuya escalera de ingreso se presentaba la lista de los 100 artistas desaparecidos, mientras que en el living de la casa se exponían una serie de obras de arte contemporáneo. Aunque es difícil saber cuán concurrido fue este evento, es importante remarcar que se publicó una crónica en el Washington Post, lo que habrá extendido la repercusión del mismo a un público considerablemente más amplio que los propios visitantes ${ }^{86}$.

En Ginebra, un día después del sexto aniversario del golpe de Estado, el 25 de marzo de 1982, la sección suiza de AIDA inició un programa de acciones por la campaña argentina. En primer lugar realizó una exposición en la Iglesia Sagrado Corazón, en el centro de la ciudad (a metros del Teatro du Grütli y a 200 metros del Gran Teatro de Ginebra), con obras de artistas de todo el mundo ya presentadas en Ámsterdam y París junto a otras de Ricardo Carpani, Hugo Pereyra y Pedro Pont Vergés ${ }^{87}$. Luego, tras un concierto del grupo "I Vitelloni”, se proyectó la película de Raymundo Gleyzer "México: La revolución congelada” (1971, 66 min. $)^{88}$. Al día siguiente, la secretaria de AIDA-Suiza,

\footnotetext{
${ }^{82}$ Esta práctica de recurrir una foto de identidad y constituir una pancarta junto a la fecha de desaparición y el vínculo que lo unía a dicha persona era utilizada en Argentina, primero de una manera más espontánea en el recorrido de los familiares por cárceles y hospitales, luego sistematizada. Cf. Ana Longoni, "Fotos y siluetas: políticas visuales en el movimiento de derechos humanos en Argentina", Afterall journal, 25, Andalucía 2010, 5-17; Ludmila da Silva Catela, "Lo invisible revelado. El uso de fotografías como (re) presentación de la desaparición de personas en Argentina", Claudia Feld y Jessica Stites Mor (eds.), El pasado que miramos, Buenos Aires, Paidós, 2009, 337-361.

${ }^{83}$ Registrado en la película “¿Dónde están?” de Anne Barbey. Algunos testimonios describen la gran emoción provocada por la belleza estética y el trabajo conjunto, como lo relata María Teresa Costantín. En la video-instalación "Memorias del exilio" (María Bagnat, Argentina, 2014), disponible en: https://www.youtube.com/watch?v=8h2oNWj2rVo

84 en "Cien banderas por cien artistas", art. Cit.

${ }^{85}$ Idem. Ver, por ejemplo, Dominique Pierce y Alain Pagano, Reportaje televisivo de, Antenne 2, du 14 novembre 1981, 20h - La navette Columbia, Archives INA (Institut National de l'Audiovisuel), Francia. URL : https://www.youtube.com/watch?v=MfLBaUj63wE (Minutos 19:50 - 21:30).

${ }^{86}$ Carla Hall, "Artist \&", Washington Post, 12 de febrero de 1982.

87 "Les trois objectifs de l'AIDA", La Tribune de Genève, 3 de febrero de 1982.

${ }^{88}$ La película habría sido difundida previamente en París, ya que se encuentra una traducción al francés del texto en los archivos de la Cartoucherie y porque se publicó una carta de su madre Sara de Gleyzer traducida al francés en la que ésta
} 
la actriz Hélène Friedli, presentó en la Embajada de Argentina una carpeta exigiendo información sobre los cien artistas desaparecidos ${ }^{89}$. Finalmente, el sábado 27 , realizaron una marcha con algunas de las pinturas-banderas de París y otras elaboradas por artistas suizos, en la que cien personas desfilaron con máscaras blancas y carteles con los nombres, profesión y fecha de desaparición de los cien artistas. También estaban presentes músicos y jóvenes con grandes racimos de globos verdes, además de celebridades como el director de cine Alain Tanner, el de teatro François Rochaix, el guitarrista clásico mexicano Alejandro Herrera, la pianista argentina Martha Argerich y el chipriota Nicolas Economou ${ }^{90}$.

Según ciertos testimonios recogidos, algunas de las pinturas-banderas realizadas para las manifestaciones habrían sido vendidas para recaudar fondos para la causa ${ }^{91}$, mientras que otras fueron enviadas a Argentina en diciembre de 1983. Trasladadas en el avión oficial de la delegación del gobierno francés a cargo del Primer Ministro Pierre Mauroy, quien asistió al traspaso de mando a las nuevas autoridades democráticas, las pinturas debían ser entregadas a las Madres de Plaza de Mayo $^{92}$. Aunque actualmente se desconoce su paradero, fueron utilizadas al menos en una de las manifestaciones de los albores de la nueva etapa democrática ${ }^{93}$. Quizás descansan aún hoy en algún depósito de dicha asociación argentina, si no fueron víctimas fatales de la humedad y del tiempo, además del olvido.

\section{Conclusión}

Ante esta actividad contra-informativa y de denuncia desde el espacio público transnacional y sobre todo desde un centro neurálgico de legitimación simbólica como es París, el gobierno argentino intentó contraatacar con una campaña que le lavara el rostro a la dictadura. AIDA denunció también esta estrategia, repudiando, por ejemplo, la exposición de Rómulo Macció que se inauguró el 8 de enero de 1982 en la Galería Bernheim Jeune ${ }^{94}$ de la capital francesa. El supuesto "Centro Cultural Argentino" que

les agradece por haber difundido el film y pregunta por las reacciones de la gente. Carta de Sara de Gleyzer a AIDA, fechada 3 de noviembre de 1981. Volante "Cent bannières dans Paris pour cent artistes disparus en Argentine", s/d, aprox. 1981.

${ }^{89}$ El Embajador aceptó recibir a una sola persona, y fue ésta la que entregó la carpeta con todas las precisiones reunidas sobre las desapariciones exigiendo al embajador respuestas al pedido de que aparezcan con vida. Se señala que se intentó la misma acción en La Haya, pero ante la negativa del portero de la Embajada a atenderlos, procedieron a pegar la documentación con cinta adhesiva en la puerta. En el caso de París, el portero de la Embajada recibió la carpeta de las manos de Simone Signoret.

90 Documento "Manifestación de la AIDA en Suiza", s/d, 1982. Este documento, escrito en español y probablemente enviado a contactos en Argentina y de exiliados en distintos países, transmite el clima local y la percepción del acontecimiento como un acto inédito y exitoso en sus fines.

${ }^{91}$ Entrevista de la autora con Odile Cointepas, 7 de junio de 2016.

92 Entrevista telefónica con Liliana Andreone, 2 de agosto de 2016.

${ }^{93}$ La única evidencia de su uso en Argentina hallada hasta el momento es una fotografía de algunas de las pinturasbanderas de AIDA expuestas en la Pirámide de Mayo, en Buenos Aires. Bajo una de ellas aparece un grafiti con la consigna "Ni olvido ni amnistía. Aparición con vida". Fotografía proveniente del fondo Roberto Amigo del CEDINCI. Disponible en URL:

http://www.archivosenuso.org/ddhh-estrategia-creativa/solidaridadinternacional\#viewer=/viewer/557\%3Fas_overlay\%3Dtrue\&js=

${ }^{94}$ Recordemos que se trata de la galería famosa por haber sido la primera en exponer a los pintores impresionistas. 
financiaba dicha exposición, era sospechado de servir de camuflaje al apoyo financiero de la Embajada Argentina para sus fines políticos. Durante la inauguración, AIDA junto con otras organizaciones de defensa de Derechos Humanos (Club de Droits socialistes de l'Homme, CAIS, CO.SO.FAM), distribuyó un volante entre los asistentes para recordar lo que el régimen argentino escondía detrás de ese aparente apoyo al arte ${ }^{95}$.

Sin lugar a dudas, estas pulseadas entre sectores contestatarios y representantes de la dictadura argentina en el extranjero translucen la búsqueda de aprobación de los diferentes actores de la comunidad internacional. Parte de las estrategias de articular una mayor solidaridad fueron las manifestaciones que detallamos, las que asimismo tuvieron un carácter ritual y por lo tanto pueden ser leídas en esa clave performática: visibilizar la ausencia. En estos actos "espectaculares" realizados durante la campaña por los cien artistas argentinos desaparecidos se vislumbra una necesidad de representarlos tanto en imágenes como en puestas en escena en la que otros cuerpos u objetos asumen su nombre, de manera similar a lo que más tarde serían las manifestaciones argentinas conocidas como el "siluetazo" remarcar su identidad realizando una lista, brindando datos concretos, describiendo sus trayectorias, mostrando sus producciones culturales (las pinturas de Remo Berardo, el film de Raymundo Gleizer), lo que funciona como prueba de la represión del régimen, a la vez que dichos cuerpos y casos pierden su individualidad en el colectivo de las víctimas, en cabezas sin rostros, en máscaras, en cuerpos uniformizados vestidos de negro, quizás en señal de luto. De hecho, como hemos remarcado y como insistía AIDA, los cien casos eran tomados como uno sólo, y así se extendía a todas las víctimas del terrorismo de Estado de la Argentina.

La asociación estudiada recurre a ese doble camino en su actuar, al coordinar acciones colectivas que incluyen nombres reconocidos para otorgar fuerza a la demanda, al reclamo por la libertad de expresión que se defiende, a la vez que se sostiene gracias a una red de individuos anónimos que colaboraban desde sus posibilidades para un objetivo concreto que representa otro aún más ambicioso: el de asegurar la libertad de creación en el mundo. Finalmente no podemos dejar de remarcar que si para las marchas europeas se adoptó el símbolo del pañuelo blanco de las Madres, también estas experiencias en el extranjero habrían tenido su influencia en las nuevas estrategias de visibilización que se usaron en el Sur, inspirando a la militancia artística local y demostrando que las ideas atravesaron el Atlántico en ambas direcciones ${ }^{97}$.

\footnotetext{
95 “Un vernissage movido", 1982, Archivos de l'AIDA.

${ }^{96}$ La primera acción de este tipo fue la del 21 de septiembre de 1983. Cf. Gustavo Bruzzone y Ana Longoni (dir.), op. cit.

97 En Chile, la portada del primer número de la revista Ruptura del grupo CADA (Colectivo de Acciones de Arte) reproduce la imagen del afiche de la manifestación de Ginebra de marzo de 1982 (creado por los reconocidos diseñadores Roger Pfund y Jean-Pierre Blanchoud), a la que le agregan una máscara blanca en la parte inferior. Además, la influencia de AIDA puede juzgarse por el símbolo elegido para la revista que imita el logo de la asociación. Ruptura, $\mathrm{n}^{\circ} 1$, agosto de 1982. Asimismo, la artista Lotty Rosenfeld confirmó que este diseño inspirado en AIDA se debió a que "su propuesta comulgaba políticamente con nuestro quehacer en el Chile dictatorial". Intercambio por correo electrónico con Lotty Rosenfeld, 17 de mayo de 2016.
} 


\section{Referencias bibliográficas}

AIDA, Argentine : une culture interdite (Pièces à conviction 1976-1980), Paris, Maspero, 1981. Eduardo Anguita y Martín Caparrós, La voluntad. Una historia de la militancia revolucionaria en la Argentina, Tomo 1 (1966 - 1973), Buenos Aires, Planeta/Booket, 2006.

Esteban Buch, Música, dictadura, resistencia. La orquesta de París en Buenos Aires, 1980, Buenos Aires, FCE, 2016.

Gustavo Bruzzone y Ana Longoni (eds.), El siluetazo, Buenos Aires, Adriana Hidalgo Editora, 2008.

Moira Cristiá, "Solidaridad e identidad artística transnacional. Reflexiones sobre la experiencia de l'Association internationale de défense des artistes victimes de la répression dans le monde (1979/1983)", Nadia De Cristóforis y Susana Novick (Comp.) Jornadas. Un siglo de migraciones en la Argentina contemporánea, Instituto de Investigaciones Gino Germani, Universidad de Buenos Aires, Buenos Aires, 2016, 2-19. Disponible en:

http://pobmigraiigg.sociales.uba.ar/publicaciones/libros/.

Ludmila da Silva Catela, "Lo invisible revelado. El uso de fotografías como (re) presentación de la desaparición de personas en Argentina", Claudia Feld y Jessica Stites Mor (eds.), El pasado que miramos, Buenos Aires, Paidós, 2009, 337-361.

Marina Franco, El exilio. Argentinos en Francia durante la dictadura, Buenos Aires, Siglo XXI, 2008.

Nancy Fraser, et al, Transnacionalizing the Public Sphere, Cambridge, Polity Press, 2014.

Ulises Gorini, La rebelión de las Madres, tomo 1, Buenos Aires, Norma, 2006.

Julien Hage, Feltrinelli, Maspero, Wagenbach : une nouvelle génération d'éditeurs politiques d'extrême gauche en Europe occidentale, 1955-1982. Histoire comparée, histoire croisée, Tesis de Doctorado dirigida por M. Jean-Yves Mollier, Université de Versailles - Saint-Quentin-enYvelines, 2010.

Alain Labrousse, Argentine: Révolution et contre-révolutions, Paris, Éditions du Seuil, 1975.

Ana Longoni, "Fotos y siluetas: políticas visuales en el movimiento de derechos humanos en Argentina", Afterall journal, 25, Andalucía, 2010, 5-17.

Ana Longoni, "Fotos y siluetas: dos estrategias en la representación de los desaparecidos", Emilio Crenzel (eds.), Los desaparecidos en la Argentina. Memorias, representaciones e ideas (19832008), Buenos Aires, Biblos, 2010, 35-57.

Eduardo Mackenzie, Les Farc ou l'échec d'un communisme de combat - Colombie 1924-2005, Paris, Publibook, 2005.

Caroline Moine, "'Votre combat est le nôtre'. Les mouvements de solidarité internationale avec le Chili dans l'Europe de la Guerre froide", Monde(s), 2 :8, Rennes, 2015, 83-104.

Archie Patterson, Music \& Second Culture Post Millennium, Portland, Eurock, 2013.

Béatrice Picon-Vallin, Ariane Mnouchkine, Paris, Actes Sud Editions, 2016.

Melisa Slatman, "El Cono Sur de las dictaduras, los eslabonamientos nacionales en el interior de la Operación Cóndor y las particularidades del caso argentino", Gabriela Águila, Santiago Garaño y Pablo Scatizza (eds.), Represión estatal y violencia paraestatal en la historia reciente argentina. Nuevos abordajes a 40 años del golpe de Estado, La Plata, EDULP, 2016, 451-471.

Alejandro Tarruella, Envar "Cacho" El Kadri. El guerrillero que dejó las armas, Buenos Aires, Sudamericana, 2015. 


\author{
Fuentes periodísticas \\ Clarin (Argentina) \\ Haasche Courant (Holanda) \\ L'Humanité (Francia) \\ La Nación (Argentina) \\ La Tribune de Genève (Suiza) \\ Le Matin (Francia) \\ Le Monde (Francia) \\ Le Nouveau Film Français (Francia) \\ Le Point (Francia) \\ Le Quotidien de Paris (Francia) \\ Libération (Francia) \\ Panorama Aujourd'hui (Francia) \\ Ruptura (Chile) \\ Testimonio Latinoamericano (España) \\ Washington Post (Estados Unidos)
}

Fuentes documentales [Archivos AIDA, La Cartoucherie, París $]^{98}$.

Actas de la reunión internacional del AIDA, redactadas por Envar El Kadri, París, 18 de junio de 1983.

Apuntes sobre el proyecto de película "Los artistas que luchan por los derechos humanos", 1980.

Boletín Unifrance Film, N 2, febrero de 1980.

Carta convocando la colaboración de pintores "100 pintores para 100 artistas 'desaparecidos' en Argentina desde el Golpe de Estado de 1976", AIDA, octubre 1981.

Cuadernillo "L'Argentine: 100 artistes disparus / Argentina: 100 artists disappeared", AIDA international, marzo de 1982.

Catálogo "Remo Berardo. Peintre 'disparu’ à Buenos Aires le 8.12.1977”, s/d.

Cuadernillo "Schrei wo du kannst, Argentina", AIDA Bundesrepublik Deutschland e. V., 1981.

Cuadernos de Actas de AIDA París.

Documento mecanografiado "Manifestación de la AIDA en Suiza", s/d, circa marzo de 1982.

Invitación a la gala en homenaje a Raúl Sendic en el Grand Palais, organizada por Droits socialistes de l'homme, 11 de diciembre de 1980.

Notas "Notes pour les organisateurs de l'exposition de tableaux de Remo Berardo", s /d.

Notas "Un vernissage movido", 1982.

Notas de AIDA sobre la controversia del Festival de Unifrance, 1980.

Postales de la campaña por los 100 artistas argentinos desaparecidos, AIDA Holanda, 1981.

Proyecto titulado “Argentine: mort d'une culture?", abril de 1981.

Récépissé de la Préfecture de Paris, 03/12/1979. [Archivo particular de Jean-François Labouverie].

Transcripciones de cintas de filmación para la película "Los artistas que luchan por los derechos humanos", 1980.

Traducción al francés de la película de Raymundo Gleyzer "México: La revolución congelada" (1971, 66 min.).

\footnotetext{
98 Estos archivos serán próximamente donados a la Biblioteca Nacional de Francia François Mitterrand. Tras haber sido recientemente organizados y digitalizados por la autora de este artículo, una selección se pondrá a disposición en el sitio http://www.generiques.org/ que apunta a reunir y hacer conocer la historia y memoria de la inmigración. Asimismo, próximamente se autorizará la puesta en línea de algunos documentos en: www.archivosenuso.org.
} 
Volante "Action urgente pour Liber Forti”, AIDA, s/d, aprox. 1980.

Volante AIDA "Cent bannières dans Paris pour cent artistes disparus en Argentine", 1981.

Volante AIDA “L'Argentine: 100 artistes disparus”, 1981.

Volante AIDA “Où est Conti?”, 1981.

Volante de información "L'AIDA a un an”, s/d, circa noviembre 1980.

\section{Fuentes fotográficas}

Fotografía aérea de Gerda Van Veen, publicada en el cuadernillo "L'Argentine: 100 artistes disparus", édition AIDA international, 1982, p. 9.

Fotografías del ensayo en La Cartoucherie, de David Boeno, Torregano Collectif Presse. Publicadas en una solicitada en Libération, 11 de noviembre de 1981.

Fotografía de algunas de las pinturas-banderas de AIDA expuestas en la Pirámide de Mayo, en Buenos Aires. Fondo Roberto Amigo del CEDINCI. Disponible en URL: http://www.archivosenuso.org/ddhh-estrategia-creativa/solidaridad-

internacional\#viewer=/viewer $/ 557 \% 3$ Fas overlay\%3Dtrue\&js $=$

\section{Fuentes audiovisuales}

María Bagnat, Video-instalación "Memorias del exilio" (Argentina, 2014), disponible en URL: https://www.youtube.com/watch?v=8h2oNWj2rVo

Anne Barbey “¿Dónde están?” (Francia, 1981, 11’), Centre audiovisuel Simone de Beauvoir [distrib.], disponible en la Biblioteca Nacional de Francia, Notice ${ }^{\circ}$ FRBNF40146210.

Dominique Pierce y Alain Pagano, Reportaje televisivo de, Antenne 2, du 14 novembre 1981, 20h La navette Columbia, Archives INA (Institut National de l'audiovisuel), Francia. Disponible en URL : https://www.youtube.com/watch?v=MfLBaUj63wE (Minutos 19:50 - 21:30).

Marie-Ange Poyet y Bénédicte Delesalle, Urban Sax à Venise (1981, 10'33'), disponible en URL : https://www.youtube.com/watch?v=WxH3F6WGLjk

Fernando Solanas, Tangos. El Exilio de Gardel, (1985, Argentina/Francia, 118').

\section{Páginas web consultadas}

Ficha de Rafael Lezama en el sitio de la Secretaría de Derechos Humanos para el Pasado Reciente de la Presidencia de la República Oriental del Uruguay. URL :

http://sdh.gub.uy/inicio/documentos/fichas de desaparecidos/argentina/lezama gonzalez rafael la udelino Sitio oficial del grupo Urban Sax, URL : http://urbansax.com/

\section{Fuentes orales y testimoniales}

Entrevista personal con Liliana Andreone, Buenos Aires, 25 de junio de 2016.

Entrevista telefónica con Liliana Andreone, 2 de agosto de 2016.

Entrevista telefónica con Anne Barbey, 6 de junio de 2016.

Entrevista personal con Odile Cointepas, París, 7 de junio de 2016.

Entrevista telefónica con Antoine Del Pin, 9 de junio de 2016.

Intercambio por correo electrónico con Jean-François Labouverie, 20 de septiembre de 2016.

Intercambio por correo electrónico con Lotty Rosenfeld, 17 de mayo de 2016. 